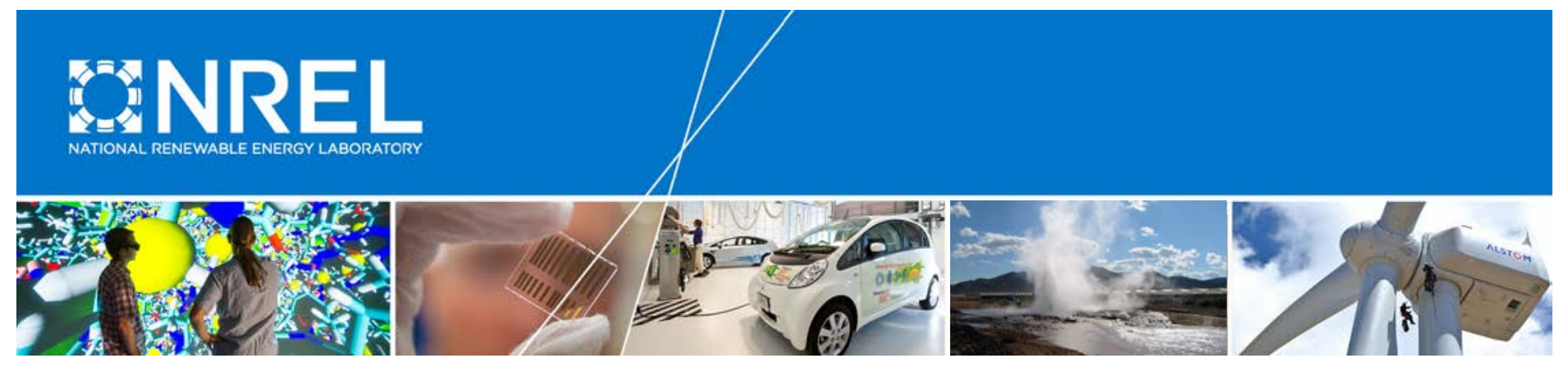

\title{
California Geothermal Forum: A Path to Increasing Geothermal Development in California
}

Katherine R. Young

National Renewable Energy Laboratory

NREL is a national laboratory of the U.S. Department of Energy Office of Energy Efficiency \& Renewable Energy Operated by the Alliance for Sustainable Energy, LLC

This report is available at no cost from the National Renewable Energy Laboratory (NREL) at www.nrel.gov/publications.

Technical Report

NREL/TP-6A20-67586

January 2017

Contract No. DE-AC36-08G028308 


\section{California Geothermal Forum: A Path to Increasing Geothermal Development in California}

Katherine R. Young

National Renewable Energy Laboratory

NREL is a national laboratory of the U.S. Department of Energy Office of Energy Efficiency \& Renewable Energy Operated by the Alliance for Sustainable Energy, LLC

This report is available at no cost from the National Renewable Energy Laboratory (NREL) at www.nrel.gov/publications.

National Renewable Energy Laboratory 15013 Denver West Parkway Golden, CO 80401

303-275-3000 • www.nrel.gov

\section{Technical Report}

NREL/TP-6A20-67586

January 2017

Contract No. DE-AC36-08G028308 


\section{NOTICE}

This report was prepared as an account of work sponsored by an agency of the United States government. Neither the United States government nor any agency thereof, nor any of their employees, makes any warranty, express or implied, or assumes any legal liability or responsibility for the accuracy, completeness, or usefulness of any information, apparatus, product, or process disclosed, or represents that its use would not infringe privately owned rights. Reference herein to any specific commercial product, process, or service by trade name, trademark, manufacturer, or otherwise does not necessarily constitute or imply its endorsement, recommendation, or favoring by the United States government or any agency thereof. The views and opinions of authors expressed herein do not necessarily state or reflect those of the United States government or any agency thereof.

This report is available at no cost from the National Renewable Energy Laboratory (NREL) at www.nrel.gov/publications.

Available electronically at SciTech Connect http:/www.osti.gov/scitech

Available for a processing fee to U.S. Department of Energy and its contractors, in paper, from:

U.S. Department of Energy

Office of Scientific and Technical Information

P.O. Box 62

Oak Ridge, TN 37831-0062

OSTI http://www.osti.gov

Phone: 865.576.8401

Fax: 865.576.5728

Email: reports@osti.gov

Available for sale to the public, in paper, from:

U.S. Department of Commerce

National Technical Information Service

5301 Shawnee Road

Alexandria, VA 22312

NTIS http://www.ntis.gov

Phone: 800.553 .6847 or 703.605 .6000

Fax: 703.605.6900

Email: orders@ntis.gov 
Contacts

Sean Porse

EGS Technology Manager

Geothermal Technologies Office

1000 Independence Ave., SW

Washington, DC 20585

Phone: 202-586-6176

E-mail: sean.porse@ee.doe.gov

\section{Eric Hass}

Hydrothermal Program Manager

Geothermal Technologies Office

13015 Denver West Blvd

Golden, CO 80401

Phone: 720-356-1558

E-mail: eric.hass@ee.doe.gov 


\section{Acknowledgments}

This conference was funded by the U.S. Department of Energy Geothermal Technologies Office (GTO), and was organized by Sean Porse, GTO; Kate Young, National Renewable Energy Laboratory; and Eric Hass and Sara Emmons, GTO. Additional support was provided by the California Energy Commission and the Geothermal Resources Council.

The organizers are grateful to all those who participated in the workshop and provided input to these conversations and recommendations. The time and insight are greatly appreciated, and will be valuable input into our future efforts. 


\section{Contents}

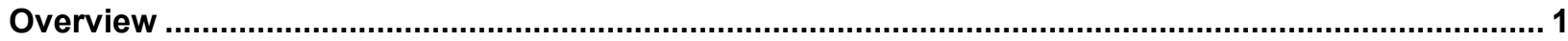

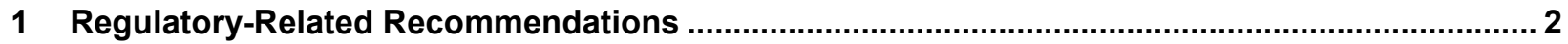

1.1 Federal funding increases for permitting authorities can lead to more efficient project

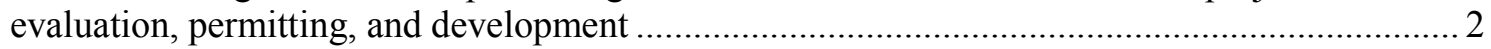

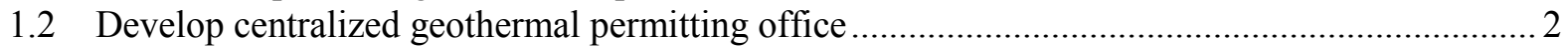

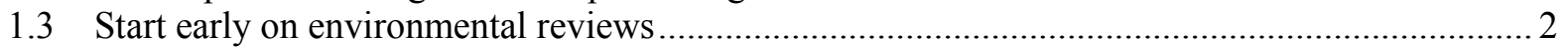

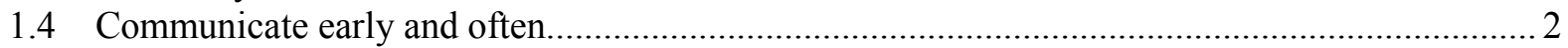

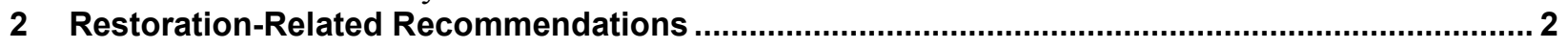

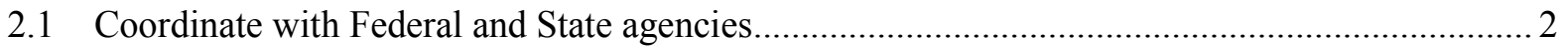

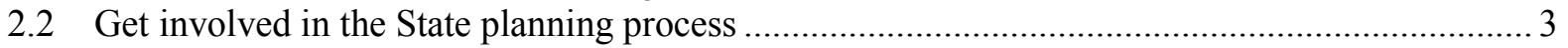

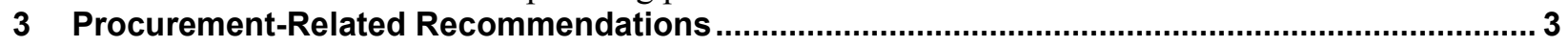

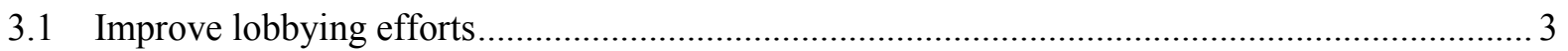

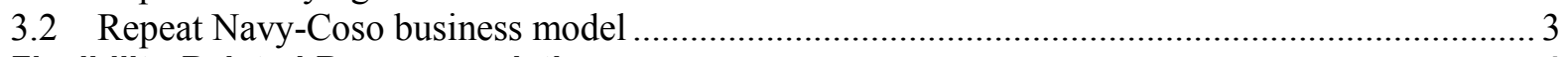

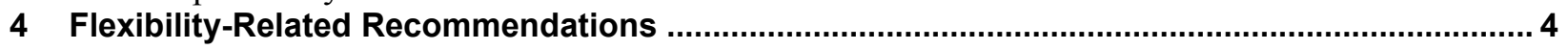

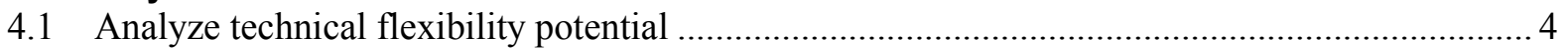

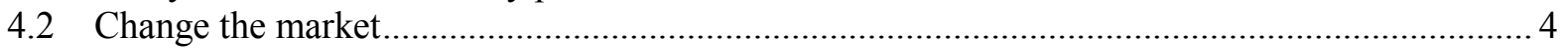

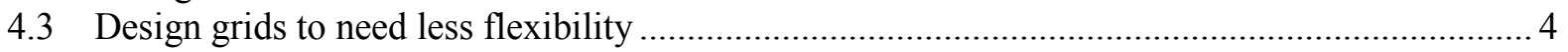

4.4 Analyze the potential for co-locating geothermal and solar................................................... 5

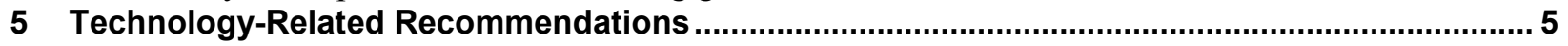

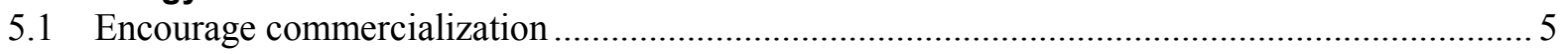

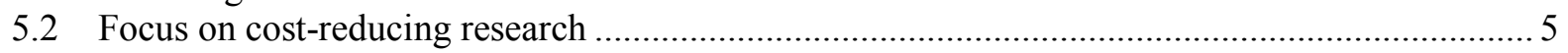

5.3 Improve subsurface understanding with advanced downhole tools .......................................... 5

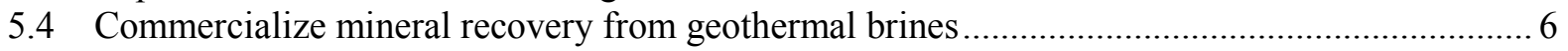

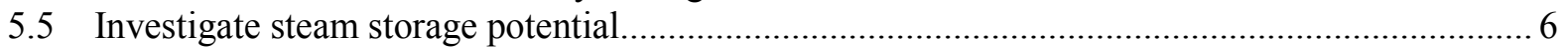

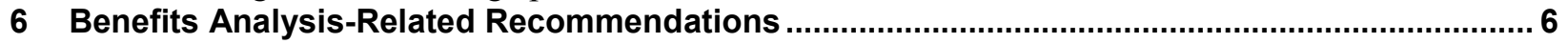

6.1 Focus on benefits to local economy ................................................................................. 6

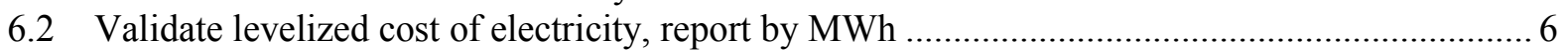

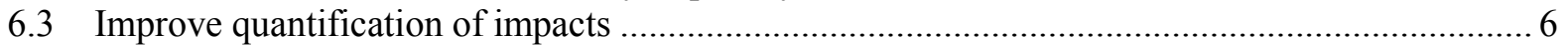

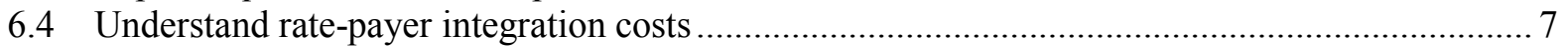

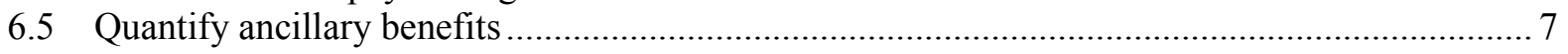

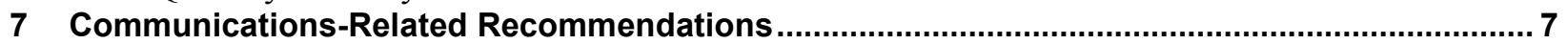

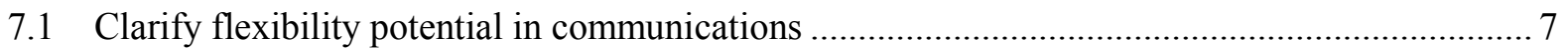

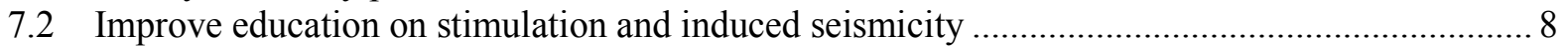

7.3 Develop impactful, memorable marketing materials ............................................................. 8 


\section{Overview}

The genesis of this report was a 2016 forum in Sacramento, California, titled "California Geothermal Forum: A Path to Increasing Geothermal Development in California." The forum was held at the California Energy Commission's (CEC) headquarters in Sacramento, California with the primary goal being to advance the dialogues for the U.S. Department of Energy's Geothermal Technologies Office (GTO) and CEC technical research and development (R\&D) focuses for future consideration. The forum convened a diverse group of stakeholders from government, industry, and research to lay out pathways for new geothermal development in California while remaining consistent with critical Federal and State conservation planning efforts, particularly at the Salton Sea.

The speakers and discussions at the forum touched on many topics-from regulation to Salton Sea restoration efforts to the latest in geothermal technology R\&D. The recommendations have been organized into the following topic areas:

1. Regulatory

2. Restoration

3. Procurement

4. Flexibility

5. Technology

6. Benefits Analysis

7. Communications.

This document, drafted by the National Renewable Energy Laboratory (NREL), is a summary of participant recommendations collected during this forum. It does not represent opinions or recommendations of the GTO, CEC, Geothermal Resource Council (GRC), or NREL. Neither the forum, nor this document, are exhaustive lists of potential research and development options, but stakeholder input like this can help inform GTO and CEC when making future decisions about potential research. The GTO is currently leading a multi-lab, multi-stakeholder effort to develop a geothermal vision study (GeoVision) that includes a summary of the latest research and a detailed roadmap for future research efforts in geothermal research in the future. More information can be found at: http://energy.gov/eere/geothermal/geothermal-vision-study.

The agenda, a list of presenters, and select presentations from the forum can be found at: https://geothermal.org/forum.html. 


\section{Regulatory-Related Recommendations}

\subsection{Federal funding increases for permitting authorities can lead to more efficient project evaluation, permitting, and development}

Delays in processing geothermal lease nominations can be caused by lack of specific geothermal funding, or lack of sufficient specialized staff. For example, in California the BLM has a backlog of nineteen competitive lease nominations and eight non-competitive applications. Leases in BLM district field offices that require a plan amendment also take more time. Increasing geothermal-specific funding, as well as staff, can help these agencies be better prepared to process leases, permits, and their associated environmental reviews in a timely manner.

\subsection{Develop centralized geothermal permitting office}

Permitting for geothermal projects on Federal lands currently takes place at local field offices, requiring a higher number of trained BLM staff, creating inconsistency in permit reviews and processing, and increasing the permitting timeframes, particularly from a lack of back-up staff. More consistent, timely, and environmentally responsible permitting may be achieved by developing a centralized geothermal permitting office where a set of trained, experienced staff process permits and environmental reviews on a consistent and timely manner, while still engaging with the local field offices that have expertise in the local resources.

\subsection{Start early on environmental reviews}

Developers with successful permitting in past development projects suggested that getting an early start on addressing resource concerns (e.g. cultural, environmental) helps ensure that State and Federal environmental reviews progress smoothly and quickly. In one example provided from the Coso geothermal field, a programmatic memorandum of agreement for the Navy was developed and signed from local and national officials to address local cultural concerns upfront, streamlining coordination between multiple levels of management and ultimately project development.

\subsection{Communicate early and often}

Many of the geothermal resources in California are near military bases and/or near areas of military operation. When development impacts throughput or tempo of military operations, it impacts the military's ability to perform. Development restrictions are often based on the technology used, location, and scale of the project. Communicating early and often with nearby military officials is important to help them better understand project plans and potential impacts to military operations. Developing synergistic relationships - particularly with military commanders on bases - can help to make the permitting process and environmental reviews go more smoothly and minimize the outlay of resources and funding that developers have to go through just to get to the point of a formal application.

\section{Restoration-Related Recommendations}

\subsection{Coordinate with Federal and State agencies}

It is important for the geothermal community to coordinate with relevant Federal and State agencies. For example, coordinating with agencies leading the Salton Sea management planning effort such as the California Natural Resources Agency (CNRA) as well as the U.S. Department 
of the Interior will help developers understand how the conservation and long-term planning process plans to move forward, and how the geothermal community can integrate itself into that process.

\subsection{Get involved in the State planning process}

Getting involved in the State resource planning process is critically important. State planners should be encouraged to look at a variety of scenarios, including some with more baseload options. The recent Center for Energy Efficiency and Renewable Technologies (CEERT) study, ${ }^{1}$ a follow up to California's Low-Carbon Grid Study, is one example scenario that shows an increase in value of integrating geothermal to a grid with increasing penetration of renewables statewide.

\section{Procurement-Related Recommendations}

\subsection{Improve lobbying efforts}

Proposed Senate Bill (SB) 1139 (Hueso, 2013) would have required $500 \mathrm{MW}$ of geothermal electricity procurement, but failed in the CA State Assembly. Assembly responses as to why SB 1139 did not pass focused on the legislature remaining technology neutral, particularly for renewables, despite several renewable technology-specific bills that had been passed emphasizing procurement of biofuels, bioenergy, solar, as well as energy storage technologies. A non-geothermal industry participant commented that their observation is that the geothermal industry does not currently have strong lobbyists relative to other industries. Their recommendation is to bolster lobbying efforts Statewide.

One additional recommendation was to review the Sustainable Groundwater Management Act. Developing an act like that for energy - a Sustainable Energy Management Act - may put the onus more on the county that details what counties need to do. Local benefits to counties (e.g. jobs, taxes, royalties) from geothermal development may help drive geothermal public acceptance since other renewables do not have the same local benefits.

\subsection{Repeat Navy-Coso business model}

One of the missions of the Navy's Geothermal Program Office (GPO) is to reduce the potential risk to a potential future developer on or near a military installation, where it may not be easy for developers to access military lands at all stages of development. In the late 1980s, the Coso geothermal project was developed at the Naval Air Weapons Station at China Lake on land that is $60 \%$ owned by the Navy and $40 \%$ owned by BLM. The Navy set up a business model with the operator, Coso Operating Company, which provides royalties back to the Navy. These royalties help to fund the Navy GPO to conduct additional geothermal exploration and other Navy-related renewable energy ventures. The Navy has developed a template for this partnership that can be used for other military/geothermal partnerships that includes best practices touching upon the use

\footnotetext{
${ }^{1}$ Caldwell, James H. and Dr. Liz Anthony, March 2016. The Value of Salton Sea Geothermal Development in California's Carbon Constrained Future. Center for Energy Efficiency and Renewable Technologies. Sacramento, CA. http://docketpublic.energy.ca.gov/PublicDocuments/15-RETI-02/TN211028 20160413T134844 Liz Anthony Comments The Value of Salton Sea Geothermal Develop.pdf
} 
of sundry notices for permitting of work and developing sensible royalty structures that optimize payment of construction and development costs.

\section{Flexibility-Related Recommendations}

\subsection{Analyze technical flexibility potential}

The Ormat-owned Puna geothermal plant in Hawaii is an example of the potential for geothermal power plants to operate flexibly (i.e., the local electric utility can remotely and automatically control dispatch of power). Additional studies are needed to understand what plants - including new builds and retrofits - need to be able to operate flexibly, how flexible they can be without causing technical issues, what additional cost may be incurred, and how flexible operations may affect income.

\subsection{Change the market}

Geothermal power plant costs are overwhelmingly fixed, with participants providing example of fixed to variable cost ratios of 90:10 or 97:3. Therefore, geothermal plants have minimal variable cost savings when one MWh is cut. Natural gas can save significantly more when cutting one MWh. The Hawaii Electric and Light (HELCO) pays a price for the capacity of the Puna geothermal plant (which covers capital investment) and then makes additional payments for electrons produced (which covers operational costs). Some suggest that markets in California are moving towards this model - that paying for storage is the first indicator that California utilities may pay for capacity, as well. Others suggest that because Hawaii's boundaries are much smaller and they must balance supply and demand on a smaller grid, their market is inherently different from the continental Unites States, where balancing areas are much larger. It is less expensive to buy from farther away (e.g. out-of-State wind energy) than it would be to make capacity payments. Analysis should be conducted to understand whether other U.S. markets could adapt their payment structures to be able to compensate plants for these additional costs.

\subsection{Design grids to need less flexibility}

Increasing solar deployment on grids creates what is known as the "duck curve" (for its distinctive shape) in electricity demand profile - representing a deep midday drop in net load, driven by solar supply, and a steep ramp-up in the late afternoon and into evening, as the sun sets just and home activities increase. Data show that this duck curve in California is increasing over time. ${ }^{2}$ Forum participants suggested that one way to prevent the duck curve from increasing further is to add additional baseload renewable generation, such as geothermal power, rather than additional variable energy resources. ${ }^{3}$ While solar power may be less expensive, the value of such energy may decrease with further market penetration, increasing afternoon ramp necessitation and possible curtailment.

\footnotetext{
2 e.g. St. John, Jeff, November 2016. The California Duck Curve Is Real, and Bigger Than Expected. Greentechmedia.com. Accessed: November 3, 2016. https://www.greentechmedia.com/articles/read/the-california-duck-curve-is-real-and-biggerthan-expected

${ }^{3}$ Improvements in the duck curve from adding geothermal is illustrated in the scenario outlined in Caldwell, James $\mathrm{H}$. and Dr. Liz Anthony, March 2016. The Value of Salton Sea Geothermal Development in California's Carbon Constrained Future. Center for Energy Efficiency and Renewable Technologies. Sacramento, CA. http://docketpublic.energy.ca.gov/PublicDocuments/15RETI-02/TN211028 $20160413 T 134844$ Liz Anthony Comments The Value of Salton Sea Geothermal Develop.pdf
} 


\subsection{Analyze the potential for co-locating geothermal and solar}

Co-locating geothermal and solar power, as is done at ENEL Green Power's Stillwater Solar Geothermal Hybrid Plant in Fallon, Nevada, can maximize potential for both technologies. Participants recommended that additional research be undertaken to make this concept reproducible for a variety of locations for both new builds and retro fits on existing plants.

\section{Technology-Related Recommendations}

\subsection{Encourage commercialization}

Some forum participants recognized that there have been many recent technology advances, but that these have failed to become commercialized, consequently falling into the R\&D "Valley of Death." It was recommended that research continue to push technologies to later technology readiness levels (TRLs) - past the R\&D "Valley of Death" - and into commercialization. Suggestions included increasing industrial partnerships for field demonstrations either by developing partnership models that incentivize operators to work with researchers to test new materials, developing models that can help developers address risk (e.g. novel cement testing downhole at commercial wells), or by increasing opportunities to work with DOE National Laboratories and service operators/energy companies via cooperative research and development agreements (e.g., well service companies and cement researchers).

\subsection{Focus on cost-reducing research}

As demonstrated by cost reductions in wind technology ${ }^{4}$ and more recent cost reductions in solar technologies, market penetration can be driven by low costs. Reducing capital costs-for example, through faster drilling rates (as is seen in oil and gas), less expensive materials, or improved design — can be equally impactful for geothermal deployment.

Additional ways to increase revenues on-site should also be explored, such as dispatchable desalination systems, mineral recovery, cascaded uses (e.g., desalination), using steam as storage, and solar/geothermal hybrids.

Analysis of costs drivers should also be explored. For example, how does the levelized cost of electricity (LCOE) of geothermal power change depending on the size of the plant? How does the value of geothermal power improve with economies of scale? How does the value change under different geothermal power incorporation scenarios?

\subsection{Improve subsurface understanding with advanced downhole tools}

Participants stated that one of the most significant problems the geothermal industry faces - from exploration to drilling to reservoir operation - are the challenges to understanding the mechanisms controlling subsurface dynamics. There were several recommendations to continue emphasizing R\&D efforts on developing additional tools for downhole imaging, diagnostics, lost circulation, and reservoir maintenance.

\footnotetext{
${ }^{4}$ U.S. Department of Energy, 2015. Wind Vision: A New Era for Wind Power in the United States. Accessed: December $14,2016$. http://energy.gov/eere/wind/maps/wind-vision.
} 


\subsection{Commercialize mineral recovery from geothermal brines}

Participants recognized the CEC, DOE and U.S. Department of Defense's efforts in currently funding research in mineral recovery, but recommended additional topics of focus, including:

- Market assessments - What nations and which sources provide these minerals today? What is current market (e.g., price, uses) for each mineral?

- Resource assessments - Where are these minerals and in what economically recoverable amounts? What percent of U.S. demand for each mineral can be met through recovery from geothermal brines? Is there an intrinsic value in U.S. production? Should there be a value assigned to this factor? Should stockpiles be used to address this?

- Recovery potential assessments - How can these minerals be recovered? At what cost? Are there opportunities for cost improvements? Can these recovery methods be standardized?

- Techno-economic assessments - If it is possible to recover these minerals, how much does it cost to recover each of these minerals from geothermal brines?

- Roadmapping paths to commercially developing mineral recovery resources Guidelines for mineral recovery commercialization currently do not exist. Is there an opportunity for DOE to identify steps, bridge the commercialization gap? Developing such mineral recovery technologies remains a difficult pathway to navigate with little or no precedent to work with.

\subsection{Investigate steam storage potential}

California energy markets are now looking to storage to help with the load imbalance. Research can be conducted to determine if steam could be injected and stored for flexible use at peaking times? If so, under what scenarios can such storage receive credit?

\section{Benefits Analysis-Related Recommendations}

\subsection{Focus on benefits to local economy}

Many of the speakers identified local benefits of their operating plants, for example a typical 30 MW geothermal project provides 29 full-time, living-wage, permanent jobs and \$5 million annually to the local economy. In addition, California geothermal plants pay taxes and royalties that go back into the local community. Quantifying these benefits as a comparison with other renewable technologies can help to highlight the benefits of geothermal development.

\subsection{Validate levelized cost of electricity, report by MWh}

Many participants questioned how well LCOE is known and validated with actual plant costs. It is not clear whether this is a data problem (data need correction) or a communication problem (data need to be better communicated so that the industry supports the data). Regardless, it was suggested that comparing costs on a MWh basis can provide a more realistic picture of actual costs, and also shows less dramatic cost differences between geothermal power and other renewables.

\subsection{Improve quantification of impacts}

Several sources suggest that geothermal power has some of the lowest environmental impacts of any available energy resource, but relative to other technologies, these data are not as well 
known or calibrated. It is important to better quantify the GHG emissions/carbon reduction potential and land use footprint of geothermal power to be able to quantify and report these values.

\subsection{Understand rate-payer integration costs}

The March 2016 CEERT study ${ }^{5}$ showed that the integration cost of solar to rate-payers may be significantly higher $(\$ 20-\$ 75 / \mathrm{MWh})$ than the integration cost of geothermal power at around $54 \%$ renewable market deployment. These results also show that increased grid flexibility can help to reduce the integration costs of solar, but what is the cost of this increased flexibility? And what incentive is there to increase flexibility if baseload power can also reduce costs? The CEERT study scratched the surface of this analysis, analyzing only two potential scenarios in California, but more analysis is needed to understand cost differences at other deployment levels, and to be able to communicate these benefits to States, utilities, and grid operators.

\subsection{Quantify ancillary benefits}

Geothermal power provides resource diversity to energy portfolios. California is the first State to fully realize the importance of having a diverse renewable portfolio ("duck curve" is caused by lack of diversity). ${ }^{6}$ Benefits such as dispatch and flexible ramping, and spinning and nonspinning reserves are becoming critical to maintain grid stability during times of huge swings in generation from intermittent resources. Further analyses are needed that explain and quantify the benefits of geothermal power in providing real-time economic dispatch and flexible ramping reserves, regulation up and down within a wide range, spinning reserve and frequency response reserve, and voltage regulation.

\section{Communications-Related Recommendations}

\subsection{Clarify flexibility potential in communications}

With the addition of increasing amounts of variable renewable technologies such as solar and wind to the grid, utilities are looking for power sources that have ramping capabilities to allow grid operators to balance the supply. Both Ormat (at the Puna Plant) and Calpine (at the Geysers) discussed the technical potential for their geothermal plants to provide flexible power. At the Puna plant, flexibility is achieved using an automatic generator controlled remotely by the HELCO system operator. As discussed above many operators identified that this type of operations increase costs - not only with increased payback periods for capital investments, but also due to increased operational costs (e.g. due to increased scaling).

Some suggested that the Hawaii-type market may be the market of the future - and will occur in other areas as we start approaching high penetrations of renewables. Others contend that this only occurs on Hawaii because of the relatively small balancing area. In the continental United

\footnotetext{
${ }^{5}$ Caldwell, James H. and Dr. Liz Anthony, March 2016. The Value of Salton Sea Geothermal Development in California's Carbon Constrained Future. Center for Energy Efficiency and Renewable Technologies. http://docketpublic.energy.ca.gov/PublicDocuments/15-RETI-02/TN211028 20160413T134844 Liz Anthony Comments The Value of Salton Sea Geothermal Develop.pdf

${ }^{6}$ St. John, Jeff, November 2016. The California Duck Curve Is Real, and Bigger Than Expected. Greentechmedia.com. Accessed: November 3, 2016. https://www.greentechmedia.com/articles/read/the-california-duck-curve-is-real-and-bigger-thanexpected
} 
States there is the potential for very large balancing areas, which would reduce the demand for this type of market.

Most participants seemed to agree that improved communication was necessary. While geothermal plants can technically be flexible, financially - a market that compensates for this flexibility would be required.

\subsection{Improve education on stimulation and induced seismicity}

Forum participants expressed a need to be clear about what geothermal projects are doing when compared with oil and gas operators, since many in the general public express concern from the effects of oil and gas stimulation activities. For example, the physics of fracture creation during geothermal reservoir stimulation is very different than the high-pressure stimulation used in the oil and gas industry.

Additionally, educating the public on induced seismicity potential and protocols is important. Producing fluids from reservoir can cause induced seismicity; replacing fluids into the reservoir can reduce the risk of induced seismicity. Additionally, reservoir stimulation can cause induced seismicity. Enhanced geothermal systems exhibits at Calpine's visitor center at the Geysers field in Northern California have been part of a strategy to facilitate strong relationships with communities near injection. State-of-the-art micro-seismic monitoring networks and processing used in three-dimensional modeling and visualization continues to improve Calpine's understanding of fracture networks.

\subsection{Develop impactful, memorable marketing materials}

Throughout the forum, many of the speakers pointed out benefits of geothermal development, from local benefits (such as jobs, royalties, taxes, and operations and maintenance spending) to grid stability benefits. Most of this information, however, was in the form of text, data and scientific graphics, buried in slides.

One observer noted of the geothermal industry: "Your photo of the year is pipes going underground. I realize you are engineers, but that is a limited audience that this would appeal to." Their recommendation was to develop graphics that show and clearly, succinctly, and convincingly explain geothermal benefits (e.g., those outlined in section 6) and distribute them industry-wide so others repeatedly see the same graphics, further bolstering the benefits an industry wide awareness campaign. 